\title{
Evaluation of Activity of the Crude Ethanolic Extract of Magonia pubescens St. Hil (Sapindaceae) Against Larvae of the Cattle Tick Rhipicephalus (Boophilus) microplus (Canestrini, 1887) (Acari: Ixodidae).
}

\author{
Fernando de Freitas Fernandes*, Priscilla Antunes Diógenes Bessa, Edméia de Paula e \\ Souza Freitas \\ Laboratório de Artropodologia Médica Veterinária; Instituto de Patologia Tropical e Saúde Pública; Universidade \\ Federal de Goiás; Rua Delenda Rezende de Melo s/n; C. P.: 131; fernandesff@pq.cnpq.br; 74605-050; Goiânia - \\ Goiás - Brasil.
}

\begin{abstract}
The acaricidal potential of the crude ethanolic extract (c.e.e.) of the stem peel of Magonia pubescens was evaluated against larvae of Rhipicephalus (Boophilus) microplus. The larvae were placed in filter paper envelopes impregnated with different concentrations of c.e.e., dissolved in dimethylsulfoxide (DMSO) and distilled water for determination of lethal concentrations $(L C)$. The following treatments were used: 1. Envelopes of dry filter paper; 2. Envelopes of filter paper moistened with distilled water; 3. Envelopes of filter paper moistened with a solution of DMSO in distilled water; and 4. Envelopes moistened with $2 \mathrm{~mL}$ of each concentration of the c.e.e. to be tested. The bioassays were carried out in quadruplicate at $27^{\circ} \pm 1^{\circ} \mathrm{C}$ and $\mathrm{RH} \geq 80 \%$ and $12 \mathrm{~h}$ light. Mortality was observed after $48 \mathrm{~h}, L C_{50}$ and $L C_{99}$ values of 365 and 4,000 ppm being obtained. There was no significant mortality in larvae exposed to the first three treatments $(p<0.05)$.
\end{abstract}

Key words: Botanical acaricide, Sapindaceae, Magonia pubescens, tinguí-do-cerrado, Boophilus microplus, cattle tick

\section{INTRODUCTION}

The active principles of plants with acaricidal properties are a promising alternative for the control of ticks and others arthropods (Prates et al., 1993; Ventura and Ito, 2000; Chagas et. al., 2002; Fernandes et al., 2005, 2007, 2008; Fernandes and Freitas, 2007).

Recent analyses of molecular phylogeny showed that the five species of Boophilus belong to the genus Rhipicephalus, so that the former should be relegated to the status of a subgenus (Beati and
Keirans, 2001; Murrel and Barker, 2003; BarrosBattesti et al., 2006).

The search of new control alternatives, more efficient and more environmentally-friendly compounds (Fernandes et al., 2005; Fernandes and Freitas, 2007; Freitas-Ribeiro et al., 2005), to Rhipicephalus (Boophilus) microplus cattle tick (Canestrini, 1887) (Acari: Ixodidae) (BarrosBattesti et al., 2006), has been driven by the growing number of reports of resistance of this genus to synthetic acaricides throughout the Neotropics (Mangold et al., 2000; Fernandes 2000, 2001; Fernandes and Freitas, 2001; Santamaría

* Author for correspondence 
Vargas et al., 2003), as well as detrimental environmental effects resulting from accumulation of chemical residues in the food chain. The principal advantages of botanical acaricides are their low toxicity to mammals, rapid degradation in the environment and slow development of resistance to them in ticks (Chungsamarnyart et al., 1991). The plants from which they are derived thus constitute a valuable natural resource (Cascon and Gilbert, 2000).

Several plants have already been evaluated for $R$. (B.) microplus control. Chemical components of the essential oils of Melinis minutiflora Beauv, especially $\alpha$-pinene, have demonstrated larvicidal activity to this tick (Prates et al., 1993). Favorable results were also obtained in evaluations of the larvicidal activity to $R$. (B.) microplus of oils from three species of Eucalyptus (Myrtaceae) (Chagas et al., 2002), as well as the oleoresinous extract from Copaifera reticulata (Leguminosae: Caesalpinioideae) (Fernandes and Freitas, 2007).

The soapberry Magonia pubescens, commonly in Brazil as timboeiro", "tinguí-do-cerrado", "urucurana" or capixingui", is a plant of the Sapindaceae family, characteristic of Brazilian cerrado (Fig. 1). Although able to adapt to many different types of soil, its natural habitat is infertile areas of Brazil (GO, DF, MT, MS, MG and SP), Bolivia and Paraguay (Guarin Neto, et al., 2000). It is a tree of middle to large size, whose wood is used in construction as well as to provide fuel for smelting in Minas Gerais State. It has characteristic fruit, large and brown. Its flowers are considered important to apiculture and its seeds are used in decorative arrangements and for soap manufacture (Pott and Pott, 1994).

Other Previous study with crude ethanolic extract (c.e.e.) of the stem peel of $M$. pubescens also demonstrated larvicidal activity against larvae of the brown dog tick, $R$. sanguineus (Fernandes et al. 2008). Extracts of another soapberry, Sapindus saponaria $\mathrm{L}$. also presented larvicidal activity to both ticks $R$. (B.) microplus (Fernandes et al., 2005), and $R$. sanguineus (Fernandes et al., 2007). However, to date the effect of any type of extract of M. pubescens on $R$. (B.) microplus is unknown. The proposal of this study was to evaluate the potential of $M$. pubescens as an acaricide, against $R$. (B.) microplus.

\section{MATERIALS AND METHODS}

Engorged females of $R$. (B.) microplus were collected from naturally infested cattle on farms of the Goiânia municipal district; which had suspended use of acaricidal treatment for at least 45 days prior to the study. Gravid females were conditioned in Biological Oxygen Demand incubator at $27 \pm 1^{\circ} \mathrm{C} \mathrm{RH} \geq 80 \%$ and L12:D12h. In order to obtain larvae of uniform age, eggs were collected daily in separate screw-cap polyethylene vials (Fernandes, 2000, 2001).

Samples of $M$. pubescens stem peel for use in bioassays were from areas of Cerrado in the municipally of Francisco Sá, in the Brazilian State of Minas Gerais (Fig. 1). The samples were dried and ground down to a fine powder in a forced ventilation greenhouse at $40^{\circ} \mathrm{C}$. Subsequently $800 \mathrm{~g}$ of this powder were extracted by percolating with $1 \mathrm{~L}$ of ethanol for $72 \mathrm{~h}$ at room temperature, repeating this process and then filtering and concentrating the c.e.e. in a rotating evaporator.

A 5,000 ppm stock solution of c.e.e. was prepared 24h before each bioassay, using $1.6 \mathrm{~mL}$ of DMSO to $148.4 \mathrm{~mL}$ of distilled water. One hour in rest, after dissolution, c.e.e was homogenized for about 15 minutes in magnetic agitator, being adjusted the final volume with distilled water. After allowing the c.e.e to settle for $1 \mathrm{~h}$, it was homogenized for 15 min with a magnetic stirrer and adjusted to the final volume with distilled water.

Smaller concentrations $(4,000,3,000,2,000$, $1,800,1,500,1,000,500$ and $300 \mathrm{ppm}$ ) were obtained by sequential dilution of the stock solution in distilled water, to permit determination of lethal concentrations, particularly $\mathrm{LC}_{50}$ and $\mathrm{LC}_{99}$. These were calculated using Probit analysis (Fernandes et al., 2005, 2007), and the $\chi^{2}$ test (Fernandes 2000, 2001, Fernandes and Freitas, 2007), using Sistema Para Análises Estatísticas ${ }^{\circledR}$ (SAEG) version $9.0^{\circ}$ software

The methodology used in the present study for evaluation of larval sensitivity was based on the larval packet test (FAO, 2004; Fernandes and Freitas, 2007), with modifications to improve practicality and decrease cost, without reducing efficiency.

Larvae were exposed to tested solutions in filter paper envelopes $\left(\approx 327 \mathrm{~m}^{2}\right)$ containing micropores to allow better ventilation (Fernandes et al., 2005, 2007; Fernandes and Freitas, 2007). 

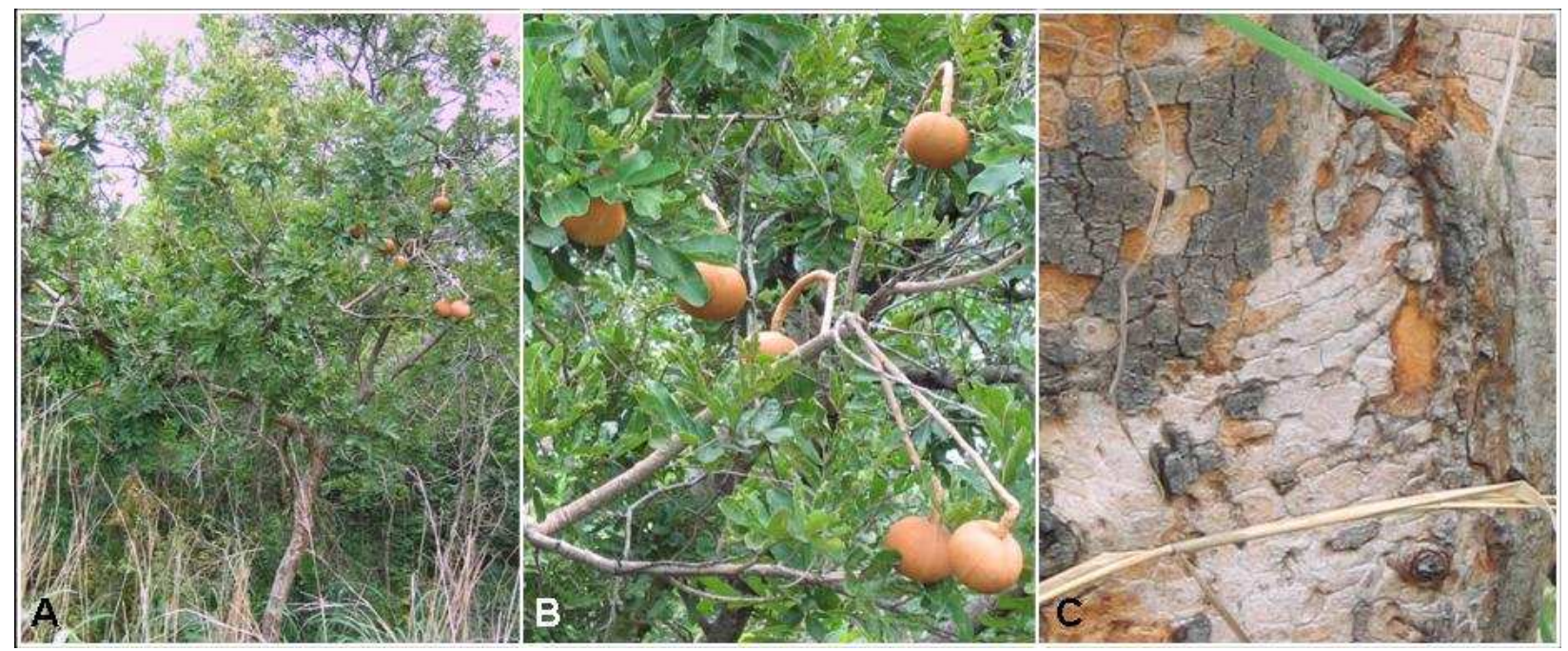

Figure 1 - Magonia pubescens: tree in its the natural Cerrado biome (A); branches, leaves and fruit (B); and stem peel (C).

The following treatments were used: 1. Envelopes of dry filter paper; 2. Envelopes of filter paper moistened with distilled water; 3 . Envelopes of filter paper moistened with a solution of DMSO in distilled water; and 4. Envelopes moistened with 2 $\mathrm{mL}$ of each concentration of the c.e.e. to be tested.

The bioassays were carried out in a specially constructed biological chamber for testing botanical acaricides at LAMV, climatizate at $27^{\circ} \pm 1^{\circ} \mathrm{C}, \mathrm{RH} \geq 80 \%$ (Fernandes et al., 2007), and approximately $12 \mathrm{~h}$ natural photophase. Hatchings tubes with the highest larval eclosion rate (90$100 \%$ ) were selected and placed in the base of a bottle, inverted in the centre of a Petri dish that was subsequently filled with water, which prevented their escape (Fernandes 2000, 2001). A sample of the larvae from this tube was put in the centre of a sheet of white paper, fixed to the bench with adhesive tape and thirty or more specimens with good mobility caught with a $n^{\circ} .4$ paintbrush moistened in test solution, then gently transferred to each envelope. The remaining larvae on the paper were killed by squashing then under adhesive tape (Fernandes and Freitas, 2007).

All larvae used in bioassays were 14-21 days old (FAO, 2004). The envelopes were sealed by folding over the $1-2 \mathrm{~cm}$ twice and fixing the folds in place with metallic clips. They were then ventilated by suspended them on hooks to prevent contact with any surface and avoid leakage of the solutions or contamination. Bioassays were carried out in quadruplicate. Fresh stock solution and four new envelopes/treatment were prepared for each replicate (Fernandes and Freitas, 2007).

Larval mortality was noted after $48 \mathrm{~h}$ exposure, when envelopes were opened and inspected under the stereomicroscope.

To allow comparison with data of other authors, immobilized larvae were considered to be dead (FAO, 2004). However, in the present work, replicates of control treatments that produced mortality of $5 \%$ or more were discounted and repeated, without using the Abbott's formula. This had been made to check larger rigidity in the evaluation of the larvicidal activity of the extract, eliminating possible minimal increments in the mortality, promoted by the addition of water, paper or solvents.

\section{RESULTS AND DISCUSSION}

The results of larval mortality after $48 \mathrm{~h}$ exposure to c.e.e are presented in Fig. $2\left(\chi^{2}=3.74<\chi^{2} \cdot 05\right.$ (7) $=14.06) . \mathrm{LC}_{50}$ and $\mathrm{LC}_{99}$ values of $365 \mathrm{ppm}(0.365$ $\mathrm{mg} / \mathrm{ml})$ and 4,000 ppm $(4.0 \mathrm{mg} / \mathrm{ml})$ respectively were obtained (Table 1).

Mortality was insignificant $(<5 \%)$ in the first three treatments $(p<0.005)$. The absence of mortality of larvae in dry envelopes demonstrates the absence of toxicity of filter paper, which can be recommended for use in larval sensitivity bioassays. 
The mortality absence in the $3^{\text {rd }}$ treatment (envelopes of paper filter moistened with the DMSO solution and distilled water) was as expected, based on previous assays of $R$. (B.) microplus larval sensibility to organic solvents.
However, Chagas et al. (2003) observed 22.5\% mortality in larvae of $R$. (B.) microplus after $24 \mathrm{~h}$ exposure to a higher concentration $(25 \%)$ of this solvent.

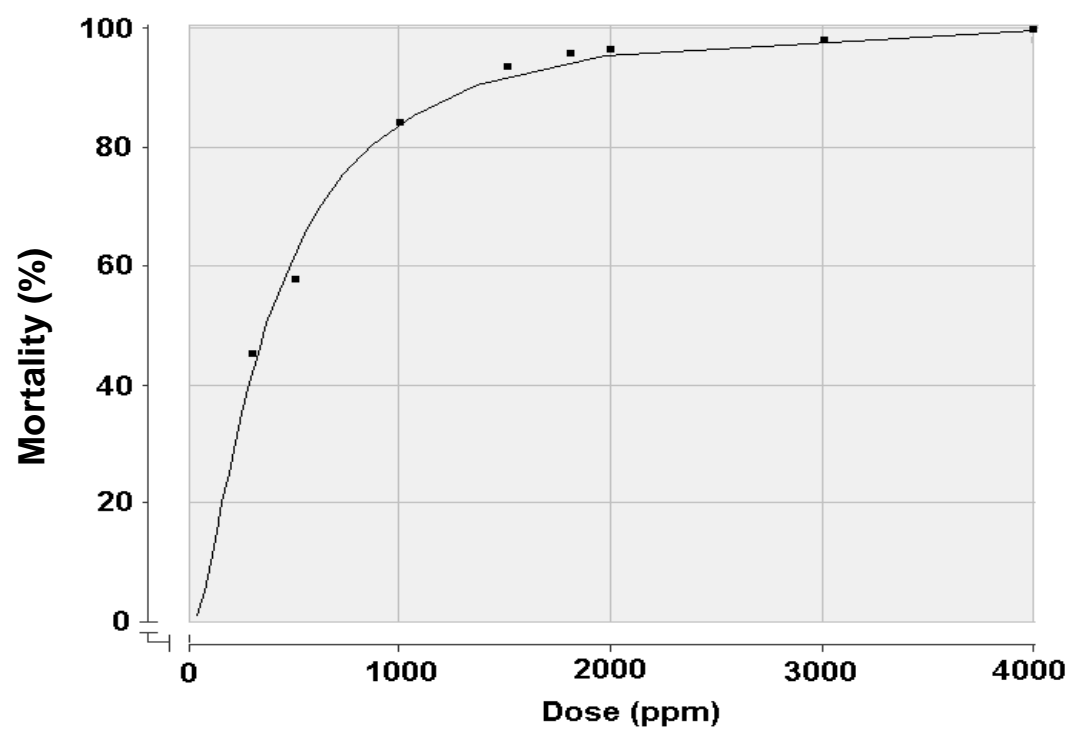

Figure 2 - Susceptibility of Rhipicephalus (Boophilus) microplus larvae to different concentrations of crude ethanolic extract of stem peel of Magonia pubescens, observed after $48 \mathrm{~h}$ exposure.

Table 1 - Susceptibility of Rhipicephalus (Boophilus) microplus larvae to different concentrations of crude ethanolic extract of the stem peel of Magonia pubescens, observed after 48h exposure.

\begin{tabular}{|c|c|c|c|c|}
\hline \multirow{2}{*}{$\begin{array}{c}\text { Lethal Concentration } \\
\text { (LC) }\end{array}$} & \multicolumn{4}{|c|}{ Level of $95 \%$ of Significance } \\
\hline & LC Values (ppm) & Minimum & - & Maximum \\
\hline $\mathrm{LC}_{45}$ & 319 & $(257.09$ & - & $379.68)$ \\
\hline $\mathrm{LC}_{50}$ & 365 & $(299.34$ & - & $428.60)$ \\
\hline $\mathrm{LC}_{55}$ & 417 & $(348.13$ & - & 484.36) \\
\hline $\mathrm{LC}_{60}$ & 472 & (399.69 & - & $542.96)$ \\
\hline $\mathrm{LC}_{65}$ & 545 & $(468.64$ & - & $621.57)$ \\
\hline $\mathrm{LC}_{70}$ & 623 & $(541.97$ & - & 706.42) \\
\hline $\mathrm{LC}_{75}$ & 727 & $(638.70$ & - & 821.69) \\
\hline $\mathrm{LC}_{80}$ & 865 & $(765.33$ & - & 980.36) \\
\hline $\mathrm{LC}_{85}$ & 1,063 & $(939.80$ & - & $1,215.69)$ \\
\hline $\mathrm{LC}_{90}$ & 1,360 & $(1,191.24$ & - & $1,588.57)$ \\
\hline $\mathrm{LC}_{95}$ & 1,969 & $(1,677.64$ & - & $2,404.53)$ \\
\hline $\mathrm{LC}_{99}$ & 4,000 & $(3,165.78$ & - & $5,436.24)$ \\
\hline
\end{tabular}

The present work implemented a higher criterion for evaluation of the mortality, with a "control group " composed of three treatments (1,2 and 3), and without applying the Abbott's formula. This had been made to check larger rigidity in the evaluation of the larvicidal activity of the extract, eliminating possible increments or addictive effect in the mortality promoted by the addition of the solvente, water ou paper. Chagas et al. (2003) they observed in larvae of $R$. (B.) microplus a mortality of $22.5 \%$ after 24 hours of exhibition to this solvent.

$M$. pubescens in the present work caused mortality of $99 \%$ of the larvae ( $\mathrm{LC}_{99}$ ) of $R$. (B.) microplus, 
in the concentration $4,000 \mathrm{ppm}(4.0 \mathrm{mg} / \mathrm{ml}) \approx 0.4$ $\%)$. Chagas et al. (2002) they verified $100 \%$ of mortality of larvae of $R$. (B.) microplus submitted to the concentration of $100,000 \mathrm{ppm}$ (100.0 $\mathrm{mg} / \mathrm{ml})(\approx 10 \%)$ of essential oil of Eucalyptus citriodora and E. staigeriana, and of 200,000 ppm $(200.0 \mathrm{mg} / \mathrm{ml})(\approx 20 \%)$ of E. globulus. Fernandes et al. (2005) they verified mortality of $99 \%$ of larvae of $R$. (B.) microplus submitted to the concentration of $6,360 \mathrm{ppm}(6.36 \mathrm{mg} / \mathrm{ml})(\approx 0.6$ $\%)$ of c.e.e of the peel of the stem of $S$. saponaria. In accordance with Fernandes et al. (2008), the larvicidal action on $R$. (B.) microplus of $M$. pubescens, could be related to the presence of tannins, previously isolated of that species (Oliveira et al., 2001).

The results obtained in this study demonstrate the larvicidal toxicity of this plant to $R$. (B.) microplus, as well as its potential to provide new compounds for larvicidal control of this species.

The larvicidal activity of $M$. pubescens demonstrated in this study was produced by the crude extract of just one part of the plant, i.e., the stem peel. Further studies should evaluate extracts of the seeds and fruit, as well as bioactive fractions of the stem peel c.e.e. The results obtained in the present study reinforce the importance of this plant as a natural resource, providing a further impetus for measures to preserve the Cerrado.

\section{ACKNOWLEDGEMENTS}

This research received partial support from Conselho Nacional de Desenvolvimento Científico e Tecnológico - Cnpq (Brazilian government entitiy promoting the scientific and tecnological development), Secretaria de Ciência e Tecnologia do Estado de Goiás (SECTEC-GO) and Fundação de Apoio à Pesquisa - UFG (FUNAPE).

\section{RESUMO}

Este trabalho objetivou avaliar o potencial acaricida do extrato-bruto etanólico (e.b.e.) da casca do caule de Magonia pubescens sobre larvas do carrapato bovino Rhipicephalus (Boophilus) microplus. As larvas foram acondicionadas em B.O.D. climatizada, em envelopes de papel filtro impregnados com diferentes concentrações do e.b.e., solubilizado com dimetilsulfóxido (DMSO) e água destilada, para determinação das Concentrações Letais (CL). Foram realizados os seguintes tratamentos: 1. envelopes de papel filtro seco; 2. envelopes de papel filtro umedecidos com água destilada; 3. envelopes de papel filtro umedecidos com solução de DMSO e água destilada; e 4. envelopes umedecidos com $2 \mathrm{~mL}$ de cada concentração do e.b.e. testada. Os bioensaios foram feitos em quadruplicata, em uma câmara climatizada a $27^{\circ} \pm 1^{\circ} \quad \mathrm{C}, \quad \mathrm{UR} \geq 80 \%$ e fotofase natural de 12 horas. A mortalidade foi observada após 48h. Obtiveram-se as $\mathrm{CL}_{50}$ de 365 e $\mathrm{CL}_{99}$ de $4.000 \mathrm{ppm}$. Não houve mortalidade significativa para os três primeiros tratamentos $(\mathrm{p}<0,05)$.

\section{REFERENCES}

Barros-Battesti, D. M., Arzua, M. and Bechara, G. H. (2006), Carrapatos de Importância MédicoVeterinária da Região Neotropical: um Guia Ilustrado para Identificação de Espécies. Vox/ICTTD-3/Butantan, São Paulo, 223pp.

Beati, L., and Keirans, J. E. (2001), Analysis of the systematic relationships among ticks of the genera Rhipicephalus and Boophilus (acari: ixodidae) based on mitochondrial 12s ribosomal Dna gene sequences and morphological characters. J. Parasitol., 87, 32-48.

Cascon, V. and Gilbert, B. (2000), Characterization of the chemical composition of oleoresins of Copaifera guianensis Desf., Copaifera duckei Dwyer and Copaifera multijuna Hayne. Phytochemistry, 55, 77378.

Chagas, A. C. S., Leite, R. C., Furlon , J., Prates, H. T. AND Passos, W. M. (2003), Sensibilidade do carrapato Boophilus microplus a solventes. Ci. Rural, 33, 109-114.

Chagas, A. C. S., Passos, M. W., Prates, H. T., Leite, R. C., Furlong, J. AND Fortes, I. C. P. (2002), Efeito acaricida de óleos essenciais e concentrados emulsionáveis de Eucalyptus spp em Boophilus microplus. Braz. J. Vet. Res. Anim. Sci., 39,247-253.

Chungsamarnyart, N., Jiwajinda, S., Ratanakreetakul, C. AND Jasawan, W. (1991), Practical extraction of sugar apple seeds against tropical cattle ticks. Kasetsart J. (Nat. Sci.), 25, 101-105.

FAO (Food and Agriculture Organization of the United Nations). (2004), Module 1. Ticks: Acaricide Resistance: Diagnosis Management and Prevention In: Guidelines Resistance Management and Integrated Parasite Control in Ruminants. Rome: FAO Animal Production and Health Division.

Fernandes, F. F AND Freitas, E. P. S. (2007), Acaricidal Activity of an oleoresinous extract from Copaifera reticulata (Leguminosae: Caesalpinioideae) Against Larvae of the Southern 
Cattle Tick, Boophilus microplus (Acari: Ixodidae). Vet. Parasitol., 147, 150-154.

Fernandes, F. F AND Freitas, E. P. S. (2001), Analysis of the use of fenthion via epicutaneous in dogs for Rhipicephalus sanguineus control. Rev. Soc. Brasil. Med. Trop., 34, 339-342.

Fernandes, F. F., Freitas, E. P. S., Costa, A. C. and Silva, I. G. (2005), Larvicidal potential of Sapindus saponaria to control of the cattle tick, Boophilus microplus. Pesq. Agropec. Bras., 40, 1243-1245.

Fernandes, F. F. (2000), In vitro activity of permetrin, cipermetrin and deltamethrin on larvae of Rhipicephalus sanguineus. Arq. Bras. Med. Vet. Zootec., 52, 621-626.

Fernandes, F. F., Leles, R. N., Silva, I. G. and Freitas, E. P. S. (2007b), Larvicidal Potencial of Sapindus saponaria (Sapindaceae) against Rhipicephalus sanguineus (Latreille, 1806) (Acari: Ixodidae). Arq. Bras. Med. Vet. Zootec., 59, 145-149.

Fernandes, F. F., D’Alessandro, W. B. and Freitas, E. P. S. (2008), Toxicity of Extract of Magonia pubescens (Sapindales: Sapindaceae) St. Hil. to Control the Brown Dog Tick, Rhipicephalus sanguineus (Latreille) (Acari: Ixodidae). Neot. Entomol., 37, 205208.

Fernandes, F. F. (2001), Toxicological effects and resistance to pyretroids in Boophilus microplus from Goiás, Brasil. Arq. Bras. Med. Vet. Zootec., 53, 548552.

Freitas-Ribeiro, G. M., Furlong, J., Vasconcelos, V.IO., Dolinski, C. and Loures-Ribeiro, A. (2005), Analysis of biological parameters of Boophilus microplus Canestrini, 1887 exposed to entomopathogenic nematodes Steinernema carpocapsae Santa Rosa and all strains (Steinernema: Rhabditida). Braz. Arch. Biol. Tech., 48, 911-919.

Guarin Neto G., Santana, S. R. AND Silva, J. V. B. (2000), Notas etnobotânicas de espécies de Sapindaceae Jusieu. Acta Bot. Bras., 14, 327-334.
Chang, C. W. (1975), Effect of fluoride pollution on plants and cattle. PhD Thesis, Banaras Hindu University, Varanasi, India

Mangold, A. J., Muñoz Cobeñas, M. E., Castelli, M. C., Scherling, N. J., Delfino, M. R. and Guglielmone, A. A. (2000), Resistência a la cipermetrina de uma populación de Boophilus microplus (Acari: Ixodidae) del norte de Santa Fé, Argentina. Rev. Méd. Vet., 81, 259-261.

Murrell, A. and Barker, S. C. (2003), Synonymy of Boophilus Curtice, 1891 with Rhipicephalus Koch, 1844 (Acari: Ixodidae). Syst. Parasitol., 56, 169-172.

Oliveira, C. M. R., Iacomini, M., Alquini, Y. AND Gorin, P. A. J. (2001), Microscopic and NMR analysis of the external coat from seeds of Magonia pubescens. New Phytologist, 152, 501-509.

Pott, A. AND Pott, V. J. (1994), Plantas do pantanal. Brasília: EMBRAPA/CPAP/SPI, 320p.

Prates, H.T., Oliveira, A. B., Leite, R. C. AND Craveiro, A. A. (1993), Atividade carrapaticida e composição química do óleo essencial do capimgordura. Pesq. Agropec. Bras., 28, 621-625.

Santamaría Vargas, M., Céspedes, N. S., Sánchez, H. F., Martins J. R., Céspedes, C. O. (2003), Avaliação in vitro de uma cepa brasileira de campo de Boophilus microplus (Acari: Ixodidae) resistente a amitraz. Ci. Rural, 33, 737-774.

Ventura, M. U. and Ito, M. (2000), Antifeedant Activity of Melia azedarach (L.) Extracts to Diabrotica speciosa (Genn.) (Coleoptera: Chrysomelidae) Beetles. Braz. Arch. Biol. Tech., 43, 215-219.

Received: March 10, 2006; Revised: November 11, 2007; Accepted: June 25, 2008. 